\title{
Evidence for maternal control of blastocyst growth after asynchronous transfer of embryos to the uterus of the ewe
}

\author{
R. A. S. Lawson, R. A. Parr and L. P. Cahill \\ Department of Agriculture, Animal Research Institute, Werribee, Victoria 3030, Australia
}

\begin{abstract}
Summary. The fate of embryos transferred asynchronously in the ewe was investigated when the functional life of the corpus luteum was prolonged by both hemihysterectomy and by the presence of a second synchronously transferred embryo. The development of asynchronously transferred embryos was assessed at progressively later stages after transfer. Prolongation of luteal function did not enable asynchronously transferred embryos to persist. Embryos from Day 4 donors were found to be retarded in their rate of development when placed in 'younger' Day 1 or 2 uteri and appeared unable to develop beyond the early blastocyst stage. Conversely, embryos from Day 4 donors placed in 'older' Day 6 or 7 uteri showed accelerated growth and development which was maintained until the uterus reached Day 12 . Thereafter further growth of the asynchronously transferred embryos was retarded, although synchronously transferred embryos then entered the phase of rapid blastodermic vesicle elongation. Asynchronously transferred embryos disappeared from the uterus when the ewe entered pro-oestrus.

The experiments demonstrate the existence of an active relationship between the embryo and the maternal environment during mid-cycle and an apparent lack of association between embryo size, growth rate and physiological maturation.
\end{abstract}

\section{Introduction}

For pregnancy to be established by the transfer of developing embryos between ewes, it is necessary to ensure that the oestrous cycles of donor and recipient are closely synchronized (Moore \& Shelton, 1964; Rowson \& Moor, 1966a). In all of the species in which embryo transfer has been attempted the embryos need to enter a reproductive tract which has experienced a period of dioestrus equivalent to the post-ovulatory age of the embryo. Chang (1950) found that rabbit blastocysts degenerated when transferred more than 2 days asynchronously. In the rat, asynchronously transferred embryos continued to develop to the time of implantation (Dickmann \& Noyes, 1960; Noyes \& Dickmann, 1960): blastocysts older than the recipient uterus showed delayed development and then implanted when the uterus became receptive while those 'younger than the recipient uterus' degenerated rapidly at this time. Similarly, in the mouse asynchronously transferred embryos older than the recipient uterus were able to implant but those which were younger degenerated (Doyle, Gates \& Noyes, 1963).

Implantation in the ewe is a slower and less precisely defined event than it is in rats and mice. The earliest sign of attachment between the trophoblastic vesicle and the endometrium cannot be detected macroscopically before Day 15 (Day 0 = day of oestrus) (Boshier, 1969). By Day 12, however, the embryo has to influence the maternal system to prevent regression of the corpus 
luteum (CL). The synchronous relationship between the uterus and the conceptus on Day 12 to prevent luteolysis has been demonstrated by Moor \& Rowson (1964, 1966a, b).

The present experiments were designed to establish whether the failure of asynchronously transferred embryos to survive in the ewe was primarily a function of an inability to provide a correct luteotrophic stimulus or whether some other crisis in the embryo-maternal relationship caused their death.

\section{Materials and General Methods}

The procedures used for the recovery and transfer of embryos and the recovery of conceptuses in these experiments were similar to those described by Hunter, Adams \& Rowson (1955) and Rowson \& Moor (1966a, b). Superovulation was induced in donor ewes by injection on Day 12 of 900-1200 i.u. PMSG (Folligon, Intervet) or a preparation of finely ground horse pituitary suspended in saline $(9 \mathrm{~g} \mathrm{NaCl} / 1)$ and administered to the potential donor at the arbitrary rate of approximately $1 / 3 \mathrm{of}$ a pituitary per ewe. Throughout the experiments the embryos were pooled and selected at random for transfer to the recipient ewes. Vasectomized rams fitted with harnesses and crayons were used to detect oestrus. The flocks were inspected daily and marked ewes were taken from the main flock. Conceptuses were examined with a dissecting microscope $(\times 50)$. Embryos were measured against an eye-piece scale: blastocyst diameter was taken at a right-angle to the embryonic disc and the lengths of blastodermic vesicles were measured with calipers.

\section{Detailed Methods and Results}

\section{Experiment 1}

This experiment was to determine whether an asynchronously transferred embryo could survive and develop if a second synchronously transferred embryo was present to maintain the CL of the recipient ewe.

Methods. Nine Suffolk ewes were used as recipients and the donors were Suffolk or Welsh Mountain ewes mated with Suffolk or Finnish Landrace rams such that the origins of any progeny were identifiable by the presence or absence of facial pigmentation. In addition to an embryo from a synchronous donor, 3 recipient ewes received embryos from donors which had been in oestrus 3 days earlier (donor +3 ) and the remaining 6 recipients received embryos from donors which had been in oestrus 3 days later (donor -3 ). Each recipient ewe received a 'white face' and 'black face' embryo, placed in each of the uterine horns of the recipient. After surgery the recipient ewes were kept with vasectomized rams and observed for marks indicative of their return to oestrus. Ewes which did not return to oestrus were slaughtered between Days 116 and 120 of gestation. Pigmentation of face cover which is evident in the fetus by Day 104 (Green \& Winters, 1945) was used to determine the origin of any surviving fetus.

Results. Eight of the ewes remained pregnant and all the surviving fetuses were from the synchronously transferred embryo. There was no indication that the presence of a $\mathrm{CL}$ would permit the continued development of the second embryo that was asynchronously transferred.

\section{Experiment 2}

The development of asynchronously transferred embryos was examined in recipient ewes in which the life of the corpus luteum was prolonged by hemihysterectomy (Moor \& Rowson, 1966c).

Methods. Blastocysts were obtained from 7 Welsh Mountain ewes treated with PMSG and operated on between Days 7 and 11 after oestrus. The blastocysts were transferred in pairs to the 
remaining uterine horn of 19 hemihysterectomized Suffolk and Welsh Mountain ewes, each of which had been in oestrus 3 or 4 days later than the respective donor (donor +3 or +4 days). In the recipient ewes a uterine horn ipsilateral to an ovulating ovary was excised immediately before the blastocysts were transferred to the remaining horn and the CL was marked with sterile India ink. With the exception of one ewe autopsied on Day 15, the recipient ewes were slaughtered during the 4th week of gestation and their uterine contents examined for products of conception.

Results. In all 19 of the hemihysterectomized recipients the CL marked at the time of transfer appeared to be functional when examined. In 4 ewes, debris which appeared to be derived from resorbing blastodermic vesicles was observed and 2 ewes had live embryos which appeared normal for the 4th week of gestation. In the remaining 12 ewes there was no evidence of conception. The ewe autopsied on Day 15 of gestation had 2 apparently normal blastodermic vesicles.

This experiment indicated that, despite the 3-4 days asynchrony between embryo and recipient, some transferred embryos were able to continue their development into the 4th week of gestation when the CL was maintained.

\section{Experiment 3}

Asynchronously transferred embryos were examined 4 days after their initial transfer to mature Border Leicester $\times$ Merino ewes.

Methods. Embryos were recovered at the 16-cell stage on Day 4 and blastocysts on Day 9 from donor ewes. The 16-cell embryos (2-4/ewe) were transferred into recipient ewes which were at Day 4 (control), Day 1 (donor -3 ) or Day 7 (donor +3 ). The blastocysts were transferred in pairs to Day 9 (control), Day 6 (donor -3 ) or Day 12 (donor +3 ) recipient ewes. Preliminary experiments had shown that embryos transferred into recipients on Day 1 could not be recovered and a ligature was thereafter placed at the cervical end of the uterine horn into which these embryos were transferred to retain the embryo. At 4 days after their initial transfer the embryos were recovered from the recipient ewes, examined microscopically and their stages of development recorded. Expanded blastocysts or blastodermic vesicles were measured. The unfertilized ova of the recipient ewes were usually recovered.

Results. There were good recovery rates of transferred embryos $(52-89 \%)$ in all groups except when 9-day-old blastocysts were transferred asynchronously into 6- or 12-day uteri (Table 1). No identifiable embryonic material could be recovered when blastocysts had been transferred into older uteri (donor +3 ) and recoveries attempted when the recipient ewes were in pro-oestrus (Day 16). The proportion of transferred blastocysts recovered from younger uteri (donor -3 ) was only $20 \%$, while $73 \%$ were recovered in the control group.

When 16-cell embryos were recovered 4 days after synchronous transfer (Table 1) all of the recovered embryos had continued to develop and the majority $(69 \%)$ had advanced to become expanded blastocysts. Exposure to more advanced uteri (donor +3 ) led to $43 \%$ of the 16 -cell embryos degenerating but $49 \%$ developed into expanded blastocysts. Although some embryos at -3 days asynchrony developed into expanded blastocysts $(24 \%)$, most were degenerate or at least retarded in their development.

Blastocysts transferred synchronously on Day 9 (Table 1) developed into elongated blastodermic vesicles $(87 \%$ but only $50 \%$ of those transferred to earlier uteri (donor -3 ) developed to this stage. None could be recovered after transfer to older uteri (donor +3$)$.

\section{Experiment 4}

Experiment 3 was repeated but the degree of asynchrony between donor and recipient was reduced from 3 to 2 days.

Methods. The 16-cell embryos recovered from recipient donors on Day 4 were transferred in pairs to Day 2 or Day 6 (donor -2 or +2 , respectively) or Day 4 (control) recipients. Recoveries of these embryos were made 6 days after the initial transfer. 
Table 1. The stage of development reached after 4 and 6 days by sheep embryos transferred as Day- 4 embryos (16-cell eggs) and after 4 days following transfer as Day-9 blastocysts with different degrees of synchrony between embryo and uterine age

\begin{tabular}{cccccccccc}
\hline & & & \multicolumn{5}{c}{ Stage of development* } \\
\cline { 5 - 10 } $\begin{array}{c}\text { Age of } \\
\text { embryo at } \\
\text { transfer }\end{array}$ & Synchrony & $\begin{array}{c}\text { Days between } \\
\text { transfer and } \\
\text { recovery }\end{array}$ & $\begin{array}{c}\text { No. embryos } \\
\text { recovered/ } \\
\text { transferred }\end{array}$ & Deg. & Mor. & + zp & - zp & Exp. & Elong. \\
\hline Day 4 & -3 & $1-5$ & $33 / 64$ & 7 & 2 & 10 & 6 & 8 & - \\
(Exp 3) & 0 & $4-8$ & $29 / 38$ & 0 & 0 & 6 & 3 & 20 & - \\
& +3 & $7-11$ & $37 / 45$ & 16 & 3 & 0 & 0 & 18 & - \\
Day 9 & -3 & $6-10$ & $10 / 51$ & - & - & - & - & 5 & 5 \\
(Exp 3) & 0 & $9-13$ & $16 / 22$ & - & - & - & - & 2 & 14 \\
& +3 & $12-16$ & $0 / 19$ & - & - & - & - & 0 & 0 \\
Day 4 & -2 & $2-8$ & $29 / 46$ & 6 & 0 & 12 & 6 & 5 & - \\
(Exp 4) & 0 & $4-10$ & $27 / 30$ & 6 & 0 & 0 & 0 & 21 & - \\
& +2 & $6-12$ & $24 / 26$ & 2 & 0 & 0 & 0 & 22 & - \\
\hline
\end{tabular}

${ }^{*}$ Deg. $=$ degenerate Mor. $=$ morula $;+\mathrm{zp}=$ blastocyst with zona pellucida $;-\mathrm{zp}=$ blastocyst without zona pellucida; Exp. = expanded blastodermic vesicle: Elong. = elongated blastodermic vesicle.

Results. The results were similar to those in Exp. 3. Embryos transferred with donor +2 day asynchrony attained a stage of blastocyst development comparable to controls but with -2 day asynchrony development was retarded (Table 1). When embryos were recovered from younger uteri (donor -2 ) many blastocysts still had a zona pellucida intact.

The growth made by blastocysts transferred into more mature uteri was dramatically accelerated (Table 2). This effect was significant and appeared to be of greater magnitude when the disparity between donor and recipient oestrous cycles was 3 days rather than 2 .

\section{Experiment 5}

The procedure followed that used in Exp. 3 and 4 but the interval to recovery was lengthened.

Methods. Embryos at the 16-cell stage (Day 4) were transferred synchronously to Day 4 or asynchronously to Day 7 recipients. Recoveries of the embryos were made at progressively later stages when the recipients reached Day 12, 14 or 15 of the oestrous cycles.

Results. At recovery on Day 12 (recipient) the synchronously and asynchronously transferred embryos were of comparable size, despite the 3 days difference in embryo age (Table 3). Comparable embryos in Exp. 3, transferred asynchronously and recovered a day earlier (Day 4 embryos transferred to Day 7 uteri and recovered Day 11: Table 2) had been $0.75 \pm 0.1 \mathrm{~mm}$ in diameter compared with $2 \cdot 12 \pm 0.50 \mathrm{~mm}$ (Day 4 embryos transferred to Day 7 uteri and recovered on Day 12: Table 3). This suggested that the asynchronously transferred embryos were growing rapidly in the recipient between Days 11 and 12 . The 3-day asynchronously transferred embryos continued to grow over the next 2 days and elongated from $2.12 \pm 0.58 \mathrm{~mm}$ to $8.07 \pm 2.37 \mathrm{~mm}$ between Days 12 and 14 in the recipient uterus. However, this development was overshadowed by the growth of the synchronously transferred embryos over the same period (Table 3). Asynchronously transferred embryos appeared to stop growing after they reached 11 days of age since those recovered on Day 15 were similar in length to those recovered on Day 14. No asynchronously transferred embryos could be recovered from Day 15 uteri which were in prooestrus as indicated by luteal regression, the presence of large follicles on the recipients' ovaries and the turgid state of the uterus. Embryos transferred asynchronously into older uteri therefore appeared to be destroyed (presumably expelled from the uterus) at the onset of the oestrus that resulted from their failure to prevent luteal regression. 
Table 2. Diameter of spherical blastodermic vesicles recovered from untreated ewes and from recipient ewes following the synchronous transfer of 16-cell (Day 4) embryos from donor ewes in oestrus on the same day or 2 and 3 days after the recipients, respectively (Exps 3 and 4)

\begin{tabular}{|c|c|c|c|c|c|}
\hline \multirow[b]{2}{*}{ Details of egg transfer } & \multirow{2}{*}{$\begin{array}{l}\text { Days in } \\
\text { recipient }\end{array}$} & \multicolumn{2}{|c|}{$\begin{array}{l}\text { Age after oestrus } \\
\text { at recovery (days) }\end{array}$} & \multirow{2}{*}{$\begin{array}{l}\text { No. of } \\
\text { blastocysts measured }\end{array}$} & \multirow{2}{*}{ Mean $\underset{(\mathrm{mm})}{ \pm \text { s.e.m. diam. }}$} \\
\hline & & Recipient & Blastocyst & & \\
\hline $\begin{array}{l}\text { Control ewes, } \\
\text { recovery on Day } 9^{*}\end{array}$ & - & 9 & 9 & 48 & $0.23 \pm 0.07$ \\
\hline \multicolumn{6}{|l|}{ Experiment 3} \\
\hline $\begin{array}{l}\text { Synchronous transfer of } \\
\text { Day-4 embryos to Day-4 } \\
\text { recipients }\end{array}$ & 4 & 8 & 8 & 19 & $0.19 \pm 0.02 \dagger$ \\
\hline $\begin{array}{l}\text { Asynchronous transfer of } \\
\text { Day-4 embryos to Day-7 } \\
\text { recipients }\end{array}$ & 4 & 11 & 8 & 15 & $0.75 \pm 0.10 \dagger$ \\
\hline \multicolumn{6}{|l|}{ Experiment 4} \\
\hline $\begin{array}{l}\text { Synchronous transfer of } \\
\text { Day-4 embryos to Day-4 } \\
\text { recipients }\end{array}$ & 6 & 10 & 10 & 21 & $0.29 \pm 0.03 \ddagger$ \\
\hline $\begin{array}{l}\text { Asynchronous transfer of } \\
\text { Day-4 embryos to Day-6 } \\
\text { recipients }\end{array}$ & 6 & 12 & 10 & 22 & $0.45 \pm 0.01 \ddagger$ \\
\hline
\end{tabular}

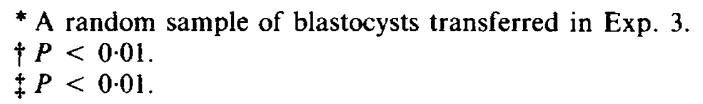

Table 3. Fate of 16-cell (Day 4) sheep embryos transferred synchronously or asynchronously to recipient ewes in oestrus on the same day or 3 days earlier, respectively, than the donors (Exp. 5)

\begin{tabular}{|c|c|c|c|c|c|c|c|c|c|}
\hline \multirow[b]{2}{*}{$\begin{array}{l}\text { Type of } \\
\text { transfer }\end{array}$} & \multicolumn{2}{|c|}{ Day of recovery } & \multirow[b]{2}{*}{$\begin{array}{l}\text { No. of } \\
\text { ewes }\end{array}$} & \multicolumn{2}{|c|}{ No. of embryos } & \multirow[b]{2}{*}{$\begin{array}{l}\text { - Recovery } \\
\text { rate }(\%)\end{array}$} & \multirow{2}{*}{$\begin{array}{l}\text { No. of } \\
\text { degenerate } \\
\text { embryos }\end{array}$} & \multicolumn{2}{|c|}{ Trophoblastic vesicles } \\
\hline & & Embryo & & Transferred & Recovered & & & No. & $\begin{array}{c}\text { Mean } \pm \text { s.e.m. } \\
\text { length }(\mathrm{mm})\end{array}$ \\
\hline $\begin{array}{l}\text { Synchronous } \\
\text { Asynchronous }\end{array}$ & $\begin{array}{l}12 \\
12\end{array}$ & $\begin{array}{r}12 \\
9\end{array}$ & $\begin{array}{l}8 \\
9\end{array}$ & $\begin{array}{l}16 \\
18\end{array}$ & $\begin{array}{l}14 \\
16\end{array}$ & $\begin{array}{l}87 \\
89\end{array}$ & $\begin{array}{l}2 \\
7\end{array}$ & $\begin{array}{r}12 \\
9\end{array}$ & $\begin{array}{l}2.23 \pm 0.36 \\
2.12 \pm 0.58\end{array}$ \\
\hline $\begin{array}{l}\text { Synchronous } \\
\text { Asynchronous }\end{array}$ & $\begin{array}{l}14 \\
14\end{array}$ & $\begin{array}{l}14 \\
11\end{array}$ & $\begin{array}{r}9 \\
10\end{array}$ & $\begin{array}{l}18 \\
19\end{array}$ & $\begin{array}{l}14 \\
16\end{array}$ & $\begin{array}{l}78 \\
84\end{array}$ & $\begin{array}{l}4 \\
9\end{array}$ & $\begin{array}{r}10 \\
7\end{array}$ & $\begin{array}{r}51.71 \pm 6.44 \dagger \\
8.07 \pm 2.37 \ddagger\end{array}$ \\
\hline Asynchronous & $\begin{array}{l}15 \\
15^{*}\end{array}$ & $\begin{array}{l}12 \\
12\end{array}$ & $\begin{array}{l}5 \\
5\end{array}$ & $\begin{array}{r}9 \\
10\end{array}$ & $\begin{array}{l}9 \\
0\end{array}$ & $\begin{array}{r}100 \\
0\end{array}$ & $\begin{array}{l}4 \\
0\end{array}$ & $\stackrel{5}{-}$ & $8.00 \pm 2.64$ \\
\hline
\end{tabular}

* Ewes in pro-oestrus.

† Mean of 7 embryos; 3 damaged in recovery were of comparable length but could not be measured.

+ Mean of 6:1 damaged in recovery.

\section{Discussion}

The most important finding in this paper is that embryos placed asynchronously in a physiologically advanced uterine environment not only survived initially, but in fact grew faster than did synchronously transferred embryos. This demonstrates the existence of an active relationship between the embryo and uterus. Although asynchronously transferred Day-9 embryos had grown to a size identical with synchronously developing embryos by Day 12 , they were unable to maintain the recipient ewe's CL. Thus embryonic growth and maturation to the stage of 
producing an appropriate anti-luteolytic stimulus appear to be separate processes. Furthermore, the inability of the embryo to prevent luteolysis even though it was growing actively up to Day 12 suggests a possible mechanism whereby preimplantation embryo mortality could be induced if uterine development was accelerated by nutritional or environmental factors. We have shown that such an acceleration of the physiological development of the uterus can be induced by progesterone treatment (Lawson \& Cahill, 1983).

This study emphasizes the need for a close synchrony between the embryo and uterus for reasons over and above the necessity to maintain the corpus luteum. When progesterone concentrations were maintained at luteal levels asynchronous embryos were unable to survive to lambing (Exp. 1) and only 2/19 survived to 4 weeks of gestation (Exp. 2). Similar results have been reported by Wilmut \& Sales (1981). These findings suggest the existence of mechanisms antagonistic to asynchronously transferred embryos which, in the ewe, serve to assist reproductive efficiency by ensuring that 'abnormally' developing embryos are unable to prevent luteal regression.

The active nature of the relationship between the embryo and the uterine environment is evident from the results of Exps 3-5. A uterine factor capable of stimulating blastocyst growth is clearly present in the uterus during mid-cycle. Day- 4 embryos grew more in 4 days when transferred to Day-7 recipients (to $0.75 \pm 0.10 \mathrm{~mm}$ ) than they did in 6 days when transferred to Day- 6 recipients (to $0.45 \pm 0.01 \mathrm{~mm}$ ) (Table 2). Growth rate was therefore related to the greater degree of asynchrony. It is not possible to interpret this observation without further investigations of the nature and duration of this uterine stimulus and the ability of embryos to respond to it. A change in embryo-maternal relationship in the period immediately after Day 12 of the oestrous cycle was evident in Exp. 5 in which 9- and 12-day-old embryos recovered from recipients on Day 12 were identical in size but 11- and 14-day-old embryos recovered on Day 14 differed enormously (Table 3). Synchronously transferred embryos therefore attain an ability for rapid development at this age which is denied to the younger asynchronous embryo, or the younger embryo may be unable to elicit an appropriate uterine stimulus to induce blastodermic vesicle elongation.

This study shows that the embryo is able to respond to physiological changes by growing in the uterus but that some aspects of embryo maturation do not keep pace, thus leading to functional asynchrony with the uterus. Such an asynchrony between the embryo and the uterine environment could be a mechanism through which early embryonic wastage is induced. Size and growth rate of embryos should not be equated with maturity or viability since these qualities appear to be independent in the early sheep embryo.

We thank Mr Doug Kerton for technical assistance; and Mr L. E. A. Rowson and Dr R. M. Moor, Animal Research Station, Cambridge, U.K., for help with Exps 1 and 2. This work was assisted by Commonwealth Sheep and Wool Research Grants.

\section{References}

Boshier, D.P. (1969) A histological and histochemical examination of implantation and early placentome formation in sheep. J. Reprod. Fert. 19, 51-61.

Chang, M.C. (1950) Development and fate of transferred rabbit ova or blastocyst in relation to the ovulation time of recipients. J. exp. Zool. 114, 197-224.

Dickmann, Z. \& Noyes, R.W. (1960) The fate of ova transferred into the uterus of the rat. J. Reprod. Fert. 1, 197-212.

Doyle, L.L., Gates, A.H. \& Noyes, R.W. (1963) Asynchronous transfer of mouse ova. Fert. Steril. 14, 215 225.

Green, W.W. \& Winters, L.M. (1945) Prenatal develop- ment of the sheep. Tech. Bull. Minn. agric. Exp. Stn 169, $1-36$.

Hunter, G.L., Adams, C.E. \& Rowson, L.E.A. (1955) Interbreed ovum transfer in sheep. J. agric. Sci., Camb. 46, 143-149.

Lawson, R.A.S. \& Cahill, L.P. (1983) Modification of the embryo-maternal relationship in the ewe by progesterone treatment early in the oestrous cycle. $J$. Reprod. Fert. 67, 473-475.

Moor, R.M. \& Rowson, L.E.A. (1964) Influence of the embryo and uterus on luteal function in the sheep. Nature, Lond. 201, 522-523.

Moor, R.M. \& Rowson, L.E.A. (1966a) The corpus 
luteum of the sheep: functional relationship between the embryo and the corpus luteum. J. Endocr. 34, 233-239.

Moor, R.M. \& Rowson, L.E.A. (1966b) The corpus luteum of the sheep: effect of the removal of embryos on luteal function. J. Endocr. 34, 497-502.

Moor, R.M. \& Rowson, L.E.A. (1966c) Local maintenance of the corpus luteum in the sheep with embryo transferred to various isolated portions of the uterus. J. Reprod. Fert. 12, 539-550.

Moore, N.W. \& Sheiton, J.N. (1964) Egg transfer in sheep. Effect of degree of synchronization between donor and recipient, age of egg and site of transfer on the survival of transferred eggs. J. Reprod. Fert. 7, 145-152.
Noyes, R.W. \& Dickmann, Z. (1960) Relationship of ovular age to endometrial development. J. Reprod. Fert. 1, 186-196.

Rowson, L.E.A. \& Moor, R.M. (1966a) Development of the sheep conceptus during the first fourteen days. $J$. Anat. 100, 777-785.

Rowson, L.E.A. \& Moor, R.M. (1966b) Embryo transfer in sheep: the significance of synchronizing oestrus in the donor and recipient animal. J. Reprod. Fert. 11, 207-212.

Wilmut, I. \& Sales, D.I. (1981) Effect of an asynchronous environment on embryonic development in sheep. $J$. Reprod. Fert. 61, 179-184.

Received 1 October 1982 